\title{
List of Plants collected in Mt. Togakushi and its Vicinities.
}

By

\author{
T. Inui, H. Hattori, and S. Kusano.

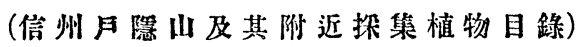

(Continued from p. 17.)

\section{Ericaceæ.}

Cassiope lycopodioides Don. イハヒゲ 奥社 Epigrea asiatica Maxim.

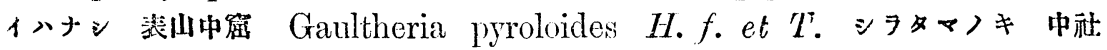
G. adenotrix Maxim. アカモ, 表山中箴 Leucothoe Grayana Maxim. ハナヒタノキ 裹山絕項 Bryanthus taxifolius A. Gray. ッがザクタ 全 Menziesia pentandra Maxim. コャゥシクッ・シ 中䖝 Rhododendron dilatatum Miq. ミッハリ、ジ 表山 R. brachyearpum G. Don. シロバナシ ヤクナゲ 吅笛 Tripetaleia bracteata Haxim. ヘコッ・ジ飯綱山 T. paniculata $S$. et $Z$ 。 ホע、沙 中社 中笜 Vaccinium uliginosum $L$. ワロ マメノキ碇山絕项 V. japonicum Miq. Thunb. a typicum Maxim. スノキ 裴山

\section{Primulaceæ.}

Primula japonica A. $G r$ r. クリンサウ 装山大䍘路 P. farinosa $L$. var. armena C $C^{y}$. Koch. Iusus japonica Malino. ニキロリサウ 百間屋屋

\section{Gentianaceæ.}

Crawfurdia japonica Sieb. et Zucc. ッッッンダウ 中神: Halenia sibirica Bork. ハナイカy 飯綱山

\section{Hydrophyllaceæ.}

Ellisiophyllum reptans Maxim. ポロギク 月隐原

\section{Borraginaceæ.}

Cynoglossum furcatum Wall. オホッリサシ 表山

\section{Asclepidaceæ.}

Cynanchum caudatum Maxim. イタく 奥社路

\section{Symplocaceæ.}

Symplocos cratregoides Ham. サハフタギ 即綱山

\section{Labiatæ.}

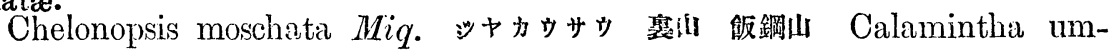

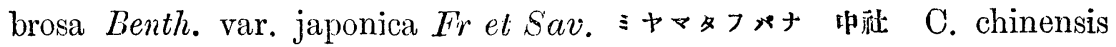
Benth. クルマバ F陵原 Dracocephalum prunelliforme Maxim. タテヤ マウ少ホ 泳山 Lycopus virginicus $L$. var. parviflorus Makino. エリ゙シロ子 巾㣂 Prunella vulgaris. $L$. var. $\gamma$ elongata Benth. サッポサ 饭綱山 
Thymus Serpyllum $L$. var. vulgaris Benth. イブキジカカサウ 表山 Plectranthus trichocarpus Maxim. クロパナヒキキコシ 中龿 Salvia japonica

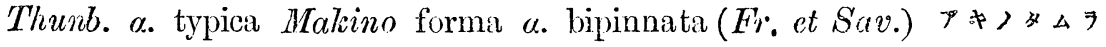

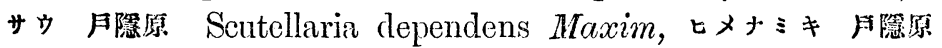

Solanaceæ.

Chamesaracha japonica Makino ( $F r$. et Sav.) pro parte) イガホッキ 中社

Scrophulariaceæ.

Pedicularis resupinata $L$. シホがマギク 飯網山 Euphrasia officinalis $L$. var. vulgaris Benth. コダメグサ 裹山總愐 Melampyrum laxum Miq. ミヤマママコナ 这山中窟 Veronica virginica $I$. var. sibirica Maxim. クがイザ 奥社路

Lentibulariaceæ.

Pinguicula vulgaris $L$. var. macroceras Herd. ムะトリスミレ 百問長屋 Caprifoliaceæ.

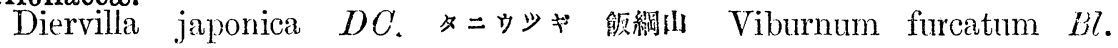

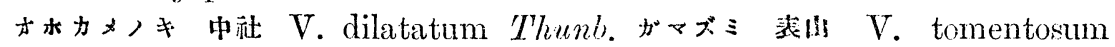

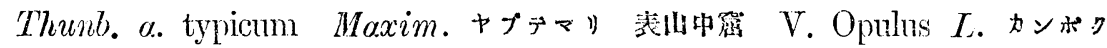
中社

Valerianaceæ.

Patrinia palmata Maxim. メクサンキミナヘン 表山中笜 P. villosa Julls. Rubiaceæ.

キトコヘシ 凤函原 P. scabiosaefolia Link. キミナヘシ 飯網原

Asperula odorata $L$. クルマバサウ 监綱原 Galium kamtschaticum Stell.

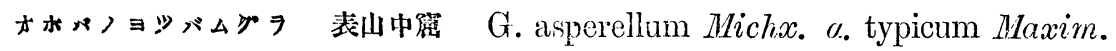

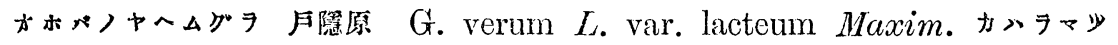
ッ舆社表山 Mitchella undulata $S$. et $Z$. ッルアリドボシ 㤗山中窟

\section{Dipsaceæ.}

Scabiosa japonica Miq. マッムシサッ奥礼月隐原

Cucurbitaceæ.

Schizopepon bryoniaefolius Maxim. var. japonica Cogn. $\$+\vee=か ゙ \pm$ ע 奥社路

Campanulaceæ.

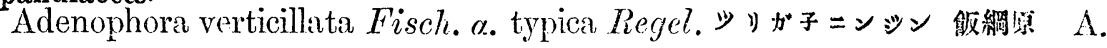

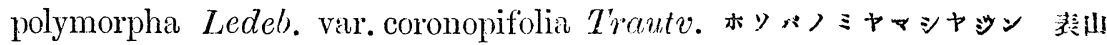
A. nikoensis Fr. et Sav. 七メシャジ 表!l A. remotiflora Hiq.

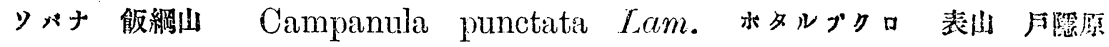
C. pilosa Pall. var. $\beta$. dasyantha Herd. チシマギキャウ 集山 Codonopsis lanceolata $B$. et $H_{\text {. }}$ ッルニンジ 奥哃 Lobelia sessilifolia Lamb. サハギキャカ 中社 F隐原 Platycodon grandiflorus $D C$. キキャ饭網原

(To be continued.) 